6. Grebin V.V. (2010). Modern streamflow regime of rivers of Ukraine (landscape-hydrology analysis). Kyiv: Nika-Centre. [In Ukrainian].

[Гребінь В.В. Сучасний водний режим річок України (ландшафтно-гідрологічний аналіз). - К. : Ніка-Центр, 2010. - 316 с.]

7. Hermanovsky Martin \& 1 Pech Pave (2013). Selection of Catchment Descriptors for the Physical Similarity Approach. Part I: Theory. Soil \& Water Research, 8(3), 133-140.

8. Laaha G., Bloschl G. (2006). A comparison of low flow regionalisation methods - catchment grouping. Journal of Hydrology. Vol. 323, 193-214.

9. Melnyk S., Loboda N. (2010). Division into districts of basin of the top Dnestr on character of fluctuations of the river runoff based on data clustering. Ukrainian hydrometeorology Journal, 6, 180-189. [In Ukrainian].

[Мельник С.В., Лобода Н.С. Районирование бассейна Верхнего Днестра по характеру колебаний годового стока на основе кластерного анализа // Укр. гідрометеорол. журн. - 2010. - № 6. - С. 180-189.]

10. Nathan R.J. (1990). Identification of homogeneous regions for the purpose of regionalization. Hydrology. Vol. 121, 217-238.

11. Onufrienko L.H. (1966). A norm and variability of annual runoff of rivers in Ukraine and Moldova. Proceedings of Ukrainian Hydrometeorological Institute. Vol. 64, 3-93. [In Russian].

[Онуфриенко Л.Г. Норма и изменчивость годового стока рек Украины и Молдавии // Труды УкрНИГМИ. - 1966. - Вып.64. - C. 3-93.]

12. Ratto Gustavo, Videla Fabián, Reyna Almandos Jorge (2014). Analysis of the Homogeneity of Wind Roses' Groups Employing Andrews' Curves. Atmospheric and Climate Sciences, 4, 447-456.

13. Voscresenky K.P. (1962). A norm and variability of an annual runoff of rivers of Soviet Union. Leningrad: Hydrometeoizdat. [In Russian].

[Воскресенский К.П. Норма и изменчивость годового стока рек Советского Союза. - Л.: Гидрометеоиздат, 1962. - 545 с.]

Стаття надійшла до редакції 6.09.2016т

УДК 551.580: 911.3 .796

doi: $10.15407 /$ ugz2016.03.033

Nhung Thu Nguyen, Bac Hoang

Institute of Geography, Vietnam Academy of Science and Technology, Hanoi

\title{
BIOCLIMATIC RESOURCES FOR TOURISM IN TAY NGUYEN, VIETNAM
}

The climate strongly influences human health and life, as well as the development of tourism activities. The climate is one of the criteria that defines the tourism development and it is also one of the factors that determines the success of travel agency. This paper refers to the relationships of climate factors and tourism in Tay Nguyen. This paper used data collected from 12 meteorological stations for the period 1980-2011 (31 years) and applied the assessment of bioclimatic model of Mieczkowski (1985) with an improvement from group of author Daniel Scott, Geoff McBoyle and Michael Schwartzentruber (2004). The results showed that tourism potential of Tay Nguyen is quite high, but traveling during the rainy season (summer) in Tay Nguyen is considered less advantageous than the dry season (winter) because of a large number of rainy days.

Keywords: tourism bioclimatic resources; Thermal comfort zone; TCI method; Tay Nguyen.

\section{Нюн Ту Нгуєн, Бак Хоан}

Інститут Географрії, Академія Наук та Технологій В'єтнаму, Ханой

\section{БІОКЛІМАТИЧНІ РЕСУРСИ ДЛЯ ТУРИЗМУ В ТАЙ НГУЄН (ЦЕНТРАЛЬНЕ ПЛАТО), В'ЄТНАМ}

Клімат справляє значний вплив на здоров'я та життя людини, а також на розвиток туристичної діяльності. Клімат - це один із критеріїв, що має визначний вплив на розвиток туризму та успіх туристичних агентств. Ця стаття висвітлює взаємозв'язок кліматичних чинників і туризму в Тай Нгуєн. При дослідженні використано дані 12 метеорологічних станцій за період 1980 - 2011 роки (31 рік) і застосовано оцінку біокліматичної моделі Mieczkowski (1985) з удосконаленням групи авторів Daniel Scott, Geoff McBoyle та Michael Schwartzentruber (2004). Результати показали, що туристичний потенціал Тай Нгуєн є досить високим, але подорожі впродовж дощового сезону (влітку) в Тай Нгуєн вважаються менш сприятливими, ніж в сухий сезон (взимку) через значну кількість дощових днів.

Ключові слова: туристичні біокліматичні ресурси; термічна зона комфорту; метод TCl; Тай Нгуєн.

\section{Introduction}

Tourism plays an important role in the global economy. In 2013, tourism revenue reached US $\$ 1,159$ billion (UNWTO 2014). Therefore, tourism development attracted many scientific researches with different perspectives, including the studies of human health climate in tourism activities. The research results show that climate has closely tied to the reproductive, health and mental state of human (Phong Dao Ngoc, 1972) and climate is the determining factor in tourism, plays an important role in the three stages of a trip, which are before, during and after the migration process 


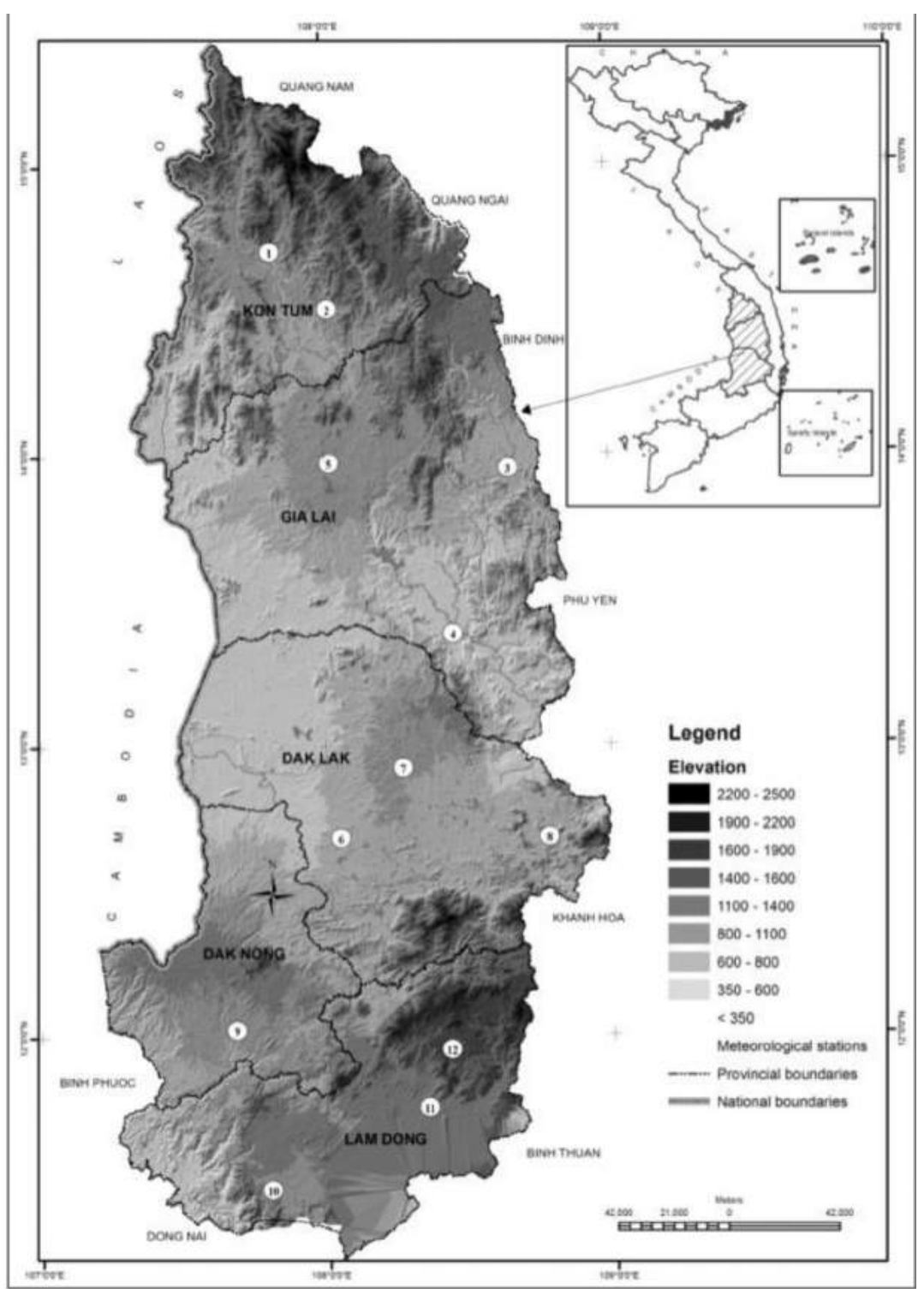

Figure 1. Geographic location of Tay Nguyen
(Abetz B, 1996). Therefore, climate will be considered as a significant criteria in the appearance of tourism places (Tavallaea, S., 2008). The survey's result for the level of interest of visitors to climatic features when they select tourist attractions of Zur Erlangung, Vorgelegt von and Wirtschaftswissenschaften (2005) shows that temperature factor (highest temperature) is the factor that visitors are the most interested in (67\% of the survey), then hours of sunshine and rainy days (50\% - 51\% of the survey). Other factors such as wind, humidity, rain, particularly ultraviolet radiation attract less tourist attention. Although the temperature factor gets much attention from tourists but it doesn't fully reflect the state of the heat of the human body with surroundings. Consequently, studying climate in tourism often uses synthetic bioclimatic index, especially tourism bioclimatic index of Mieczkowski (1985). This index has been applied successfully in many countries, especially in Europe for example by Bas Amelung, David Viner (2006), Amiranashvili, A. Matzarakis, L.Kartvelishvili (2005), Jacqueline M. Hamilton, David J. Maddison, Richard S.J. Tol, (2004), A. Matzarakis, C. R. de Freitas and D. Scott (2007), Hassan Rahmanpour . Hashem Jangi. Ali Beyk Khorasani Niya (2014).

In Vietnam, the researches on climate relation to human health in production activities and life were summarized in the folk-songs, proverbs. Trac Huu Le was the first person who summarized the rationale of experience and comments into theory basics about the relationship between climate and life. Later, the studies of the influences of climate and weather on the human body have developed strongly with the work of Yen Vinh La (1961), Phong Ngoc Dao (1972), Dac Tat Phan, Toan Ngoc Pham (1980). In recent years, according to the global trend, studying tourism and climate gets a lot of attention, and is represented by Lien Tran Viet (1993, 2009), Van Khanh Nguyen (1993), Van Khanh Nguyen, Hien Thi Nguyen (2000). In the studies, the authors have used climate indexes to assess tourism potential of different regions in Vietnam. Especially, in the study of Lien Viet Tran (2009), he used TCI Mieczkowski (1985) to evaluate tourism resources in Dien Bien, Vietnam.

\section{Geographic location}

\section{Methodology}

Tay Nguyen is the mountainous and highland area of Vietnam (including five provinces: Kontum, Gia Lai, Dak Lak, Dak Nong, Lam Dong) with geographic coordinates from 107o17' - 108o00' of east longitude and 11054' - 15o10' north latitude. Tay Nguyen has a highland - monsoon tropical climate (Fig 1). The climate of Tay Nguyen is divided into two seasons: the dry season (winter) and the rainy season (summer). The dry season starts from March to April and is quite cool but not too cold. Rainy season starts from May to October and has a warm climate. Tay Nguyen tourist season takes place throughout the year.

According to the research results of Toan Ngoc Pham, Dac Tat Phan (1980); Ngu Duc Nguyen, Hieu Trong Nguyen (1985), Tay Nguyen has annual large amoun of radiation, total radiation is around 120$140 \mathrm{kcal} / \mathrm{cm}^{2} /$ year, hours of sunlight are 2097.9 2484.3 hours/year, average temperature is $22-24^{\circ} \mathrm{C}$, humidity $>80 \%$. These are advantages for tourism 
Table 1. Parameter/Sub-indices within the tourism climate index

\begin{tabular}{|c|l|l|c|}
\hline Parameter & \multicolumn{1}{|c|}{ Climate variables } & \multicolumn{1}{c|}{ Influence on TCI } & $\begin{array}{c}\text { Level of contribution } \\
(\%)\end{array}$ \\
\hline CID & $\begin{array}{l}\text { maximum daily } \\
\text { temperature \& } \\
\text { minimum daily } \\
\text { relative humidity }\end{array}$ & $\begin{array}{l}\text { Description of thermal comfort } \\
\text { when tourist activity takes place } \\
\text { with maximum }\end{array}$ & 40 \\
\hline CIA & $\begin{array}{l}\text { mean daily } \\
\text { temperature \& mean } \\
\text { daily relative humidity }\end{array}$ & $\begin{array}{l}\text { Description of thermal comfort } \\
\text { within 24 h including sleeping }\end{array}$ & 10 \\
\hline P & total precipitation & $\begin{array}{l}\text { Reflecting negative impact of } \\
\text { tourist activities in the outdoors }\end{array}$ & 20 \\
\hline S & total hours of sunshine & $\begin{array}{l}\text { As the rate of positive } \\
\text { contributions for travel, but } \\
\text { underlying the negativebecause } \\
\text { of the risk of sunburns and more } \\
\text { uncomfortable on hot days }\end{array}$ & 20 \\
\hline W & average wind speed & $\begin{array}{l}\text { Positive in nature because of the } \\
\text { cooling effect in hot zone }\end{array}$ & 10 \\
\hline
\end{tabular}

development in Tay Nguyen. Besides, Tay Nguyen has steadfast relationships in - socio-economic and ecological environment with the South Central Coast provinces (east), southern Laos and northeast Cambodia (west), East Vietnam and the Mekong Delta (south). Therefore, Tay Nguyen have favorable conditions to expand exchanges with many domestic and international areas.

\section{Methods}

This paper uses method of analysis and the identification of tourism bioclimatic index invented by Mieczkowski (1985) with the improvement of group of authors including Daniel Scott, Geoff McBoyle and Michael Schwartzentruber (2004) to determine the extent of influences of climate factors for outdoor tourism operations. The tourism bioclimatic index is determined by the formula:

$\mathrm{TCI}=8 \mathrm{CID}+2 \mathrm{CIA}+4 \mathrm{P}+2 \mathrm{~S}+\mathrm{W}$

The relationship of the parameters in the formula above is shown in Table 1.

CID and CIA indexes are determined by ET index of Aizenshtat B.A and Lukina L.P (1982) with the threshold of heat for Vietnamese people.

- Extremely cold $\left(\mathrm{ET} \leq 8^{\circ} \mathrm{C}\right)$

- Very cold $\left(8^{\circ} \mathrm{C}<\mathrm{ET}<15^{\circ} \mathrm{C}\right)$

- Cold $\left(15^{\circ} \mathrm{C}<\mathrm{ET}<17 \circ \mathrm{C}\right)$

- Cool or slightly cold $\left(17^{\circ} \mathrm{C}<\mathrm{ET}<20^{\circ} \mathrm{C}\right)$

- Cozy $\left(20^{\circ} \mathrm{C}<\mathrm{ET}<23^{\circ} \mathrm{C}\right)$

- Cozy or a little warm $\left(23^{\circ} \mathrm{C}<\mathrm{ET}<26^{\circ} \mathrm{C}\right)$

- Hot $\left(26^{\circ} \mathrm{C}<\mathrm{ET}<30^{\circ} \mathrm{C}\right)$

- Very hot $\left(30{ }^{\circ} \mathrm{C}<\mathrm{ET}<33{ }^{\circ} \mathrm{C}\right)$

- Extremely hot $\left(\mathrm{ET}>33^{\circ} \mathrm{C}\right)$

Another components such as sunlight, rain, wind are determined based on the conception that have been presented in researches of Daniel Scott, Geoff MacBoyle, Michael (2004) Schwartzentruber, Bas Amelung, David Viner (2006).

This study used climate data in several years of 12 meteorological stations in Tay Nguyen. The TCI calculation results will lie in the range: 90-100 (Ideal), 80-89 (Excellent), 70-79 (Very good), 60-69 (Good), 50-59 (Acceptable), 40-49 (Marginal).

\section{Results and Discussion}

The TCI index (table 2) was calculated based on the measured data of 12 meteorological stations in Tay Nguyen in the period 1980-2011.

Results of calculation in table 2 show that Tay Nguyen has a great tourism potential, annual average TCI is about $60-74 \%$ (good to very good). The highest TCI is Lien Khuong (74\%) and lowest is An Khe $(52 \%)$, but at acceptable level. Although the tourism potential of the region is at average level but this potential distribution is not the same between different times of the year. Summer is usually considered to be relatively favorable for tourism activities but in Tay Nguyen summer is rainy season (from May to October). Thus, the potential of tourism climate in Tay Nguyen concentrates on the dry season (January to April). Most of provinces in region have TCI achieved good $(60-70 \%)$, very good $(70-80 \%)$, excellent $(80-$ $90 \%$ ) in the winter (dry season). Meanwhile, most of June, July, August, September, October in the summer, TCI reached acceptable levels $(50-60 \%)$, in some places, TCI only limit $(<50 \%)$, for example, Pleiku's TCI was $46-48 \%$ in three months in summer (July to 
Table 2. TCI at 12 locations in Tay Nguyen

\begin{tabular}{|c|c|c|c|c|c|c|c|c|c|c|c|c|c|c|}
\hline No & $\begin{array}{c}\text { Meteorological } \\
\text { stations }\end{array}$ & Apr. & May & June & July & Aug. & Sept. & Oct. & Nov. & Dec. & Jan. & Feb. & Mar. & Year \\
\hline 1 & Dak To & 82,0 & 90,0 & 80,0 & 78,0 & 66,0 & 62,0 & 54,0 & 50,0 & 62,0 & 66,0 & 80,0 & 76,0 & 68,0 \\
\hline 2 & Kontum & 82,0 & 80,0 & 70,0 & 64,0 & 60,0 & 56,0 & 52,0 & 52,0 & 52,0 & 62,0 & 78,0 & 82,0 & 62,0 \\
\hline 3 & Pleiku & 88,0 & 86,0 & 78,0 & 74,0 & 64,0 & 50,0 & 46,0 & 48,0 & 46,0 & 60,0 & 78,0 & 78,0 & 62,0 \\
\hline 4 & An Khe & 70,0 & 66,0 & 72,0 & 70,0 & 62,0 & 60,0 & 60,0 & 68,0 & 54,0 & 46,0 & 54,0 & 66,0 & 52,0 \\
\hline 5 & Ayun Pa & 68,0 & 72,0 & 74,0 & 64,0 & 58,0 & 66,0 & 66,0 & 60,0 & 58,0 & 56,0 & 56,0 & 68,0 & 64,0 \\
\hline 6 & M'Drak & 71,9 & 78,9 & 88,5 & 82,3 & 74,1 & 71,7 & 71,3 & 77,7 & 64,5 & 59,3 & 49,2 & 65,5 & 70,8 \\
\hline 7 & Buon Ho & 78,0 & 86,0 & 78,0 & 76,0 & 64,0 & 62,0 & 62,0 & 66,0 & 66,0 & 66,0 & 62,0 & 66,0 & 66,0 \\
\hline 8 & Buon Ma Thuot & 86,0 & 80,0 & 76,0 & 60,0 & 52,0 & 52,0 & 64,0 & 46,0 & 54,0 & 58,0 & 68,0 & 78,0 & 58,0 \\
\hline 9 & Dak Nong & 88,0 & 76,0 & 74,0 & 60,0 & 60,0 & 42,0 & 50,0 & 58,0 & 50,0 & 62,0 & 78,0 & 80,0 & 64,0 \\
\hline 10 & Bao Loc & 80,0 & 80,0 & 76,0 & 74,0 & 70,0 & 58,0 & 56,0 & 52,0 & 54,0 & 58,0 & 68,0 & 80,0 & 68,0 \\
\hline 11 & Lien Khuong & 84,0 & 86,0 & 82,0 & 74,0 & 72,0 & 66,0 & 66,0 & 62,0 & 56,0 & 68,0 & 78,0 & 80,0 & 74,0 \\
\hline 12 & Da Lat & 72,0 & 78,0 & 82,0 & 64,0 & 60,0 & 64,0 & 52,0 & 52,0 & 56,0 & 60,0 & 60,0 & 62,0 & 60,0 \\
\hline
\end{tabular}

September). However, compared with the calculated results to the global TCI of Bas Amelung, Daniel Scott (2005), the lower potential for tourism in the summer in the Tay Nguyen is appropriate. The reason is that according to the thermal comfort criterion of climates if the weather is too hot, it does not fit with activities of human body and hinder process of heat exchange. CID and CIA indexes often exceed the threshold of thermal comfort. Besides, rainy weather usually brings inappropriate conditions for tourism activity outdoors. In Tay Nguyen this indicator is usually lowvalue, even negative (Kon Tum, Pleiku, Buon Ma Thuot, Dak Nong and Bao Loc).

TCI variability of Tay Nguyen shows mostly one maximum and one minimum. The maximum appears in the dry season from December to February and
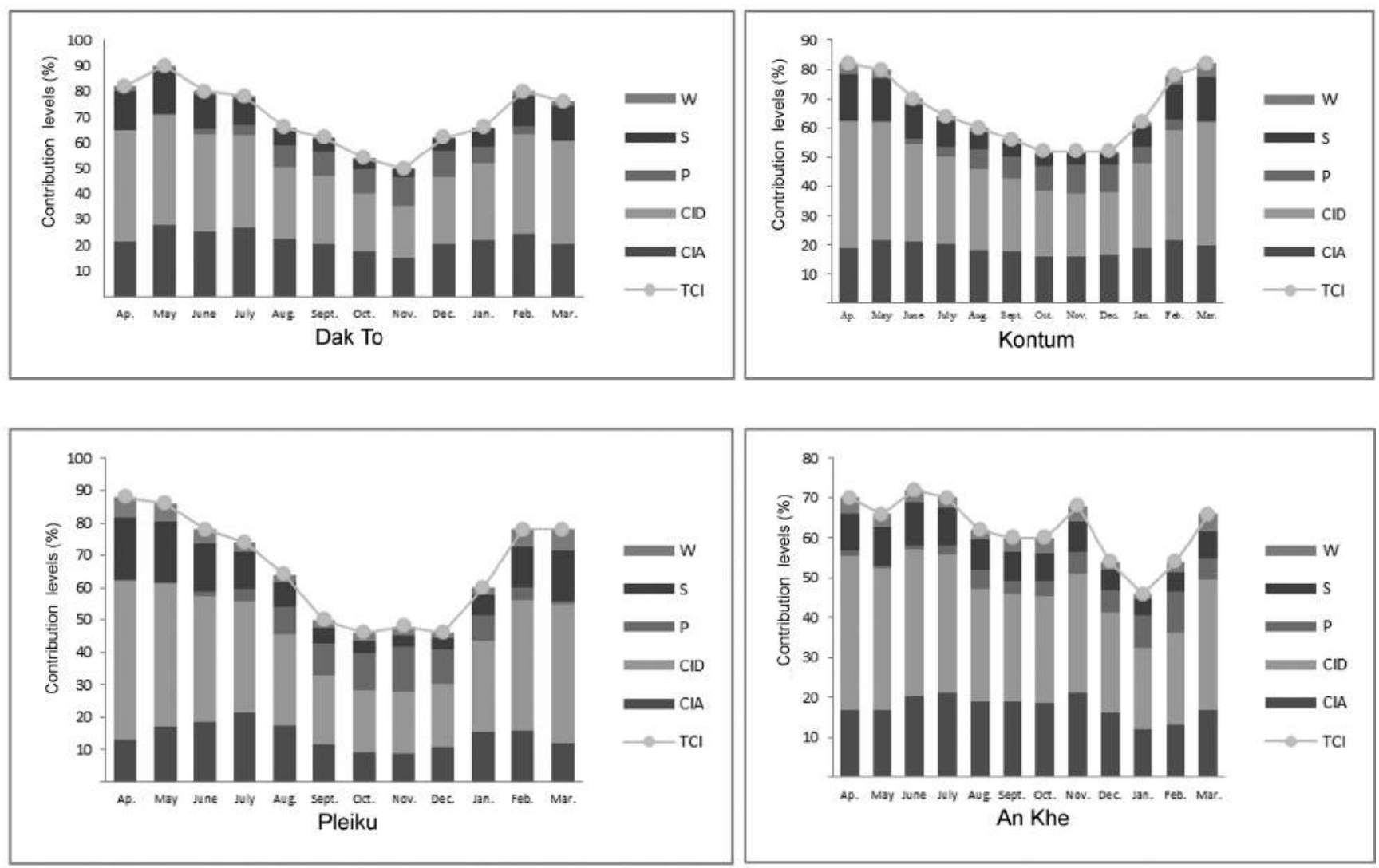

Figure 2. TCI variability and components in Tay Nguyen meteorological stations 

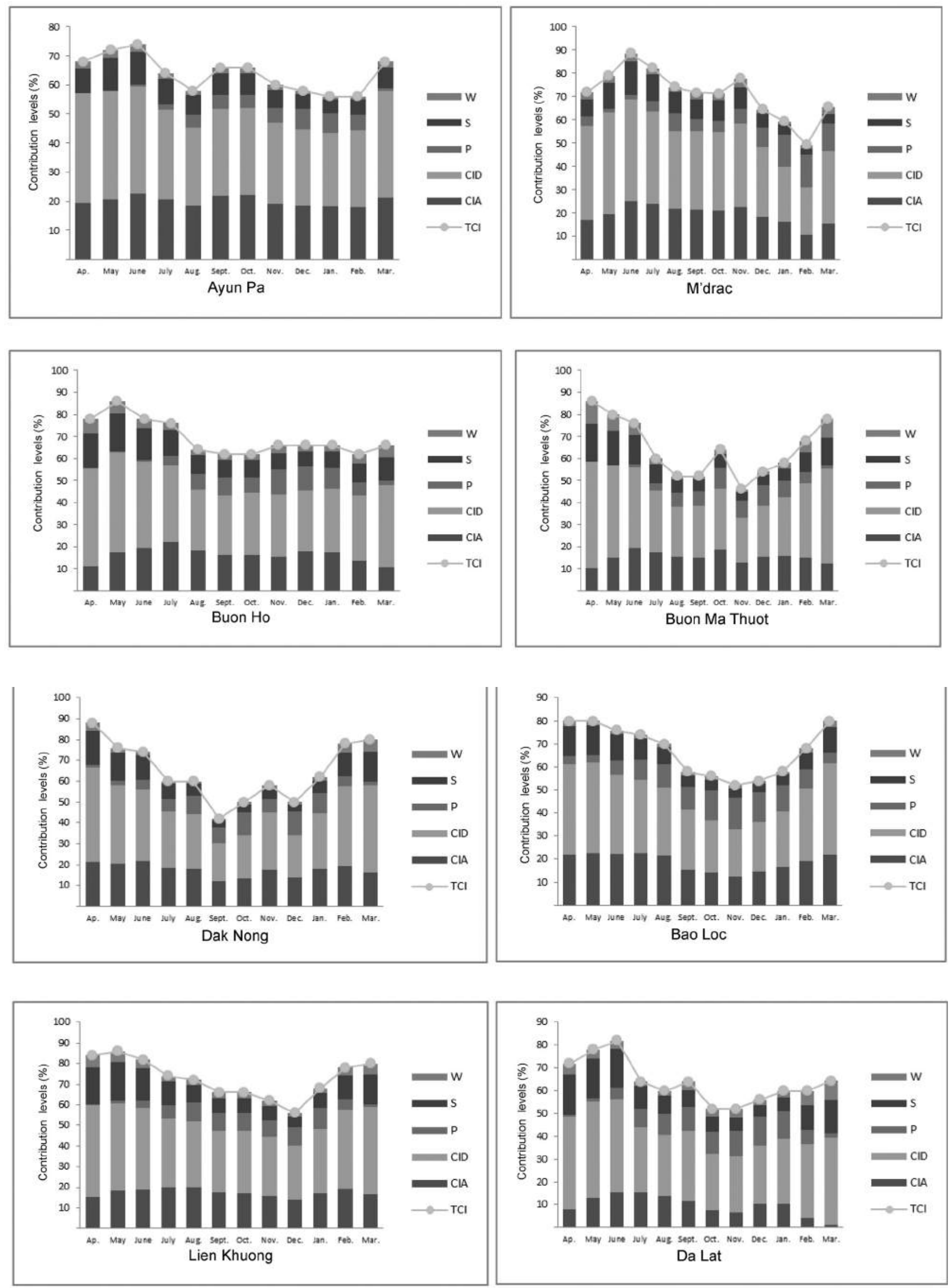

Figure 2. TCI variability and components in Tay Nguyen meteorological stations (continued) 
minimum appears on July-September. This variability exists in large parts of the area. CID and CIA played a special role in this variables. High sunshine hours and rainfall contributed to the annual TCI variation. Representatives of this case can be seen at the stations of Kontum, Pleiku, Buon Ma Thuot, Dak Nong, Bao Loc and Da lat.

The annual TCI variability also has two maximums, the main maximum falls in February and March (dry season), the sub maximum falls last months of rainy season and the beginning of dry season. In this variability, CID plays the most important role, because Tay Nguyen summer is often cooler but hampered by heavy rainfall, the typical stations are Dak To, An Khe, Ayun Pa.

\section{Conclusion}

The application of Mieczkowski's tourism bioclimatic model within Tay Nguyen, Vietnam once again affirms that tourist activities are not only impacted by the thermal state of the atmosphere but also by the other factors, such as rain, sun and wind that are less or not related to the thermal state of the environment. The research result shows that Tay Nguyen has a high tourism potential, almost all monthly indexes of the region are considered acceptable for tourism industry, except of July, August and September in Pleiku, October in An Khe, November in M'drac, August in Buon Ma Thuot and June in Dak Nong. Traveling during the rainy season (summer) in Tay Nguyen is considered less advantageous than the dry season (winter), by a sizable number of rainy days.

However, in a humid tropical climate rainfall is the basis for vegetation formation and the diversity of fauna and flora. It ensures the great abundance of local fruits and beautiful flowers. All seasons of the year attract tourists from all over the world.

\section{Acknowledgements}

Author would like to thank the Chairman of the project TN3/T03 who created good conditions for the author to use the documents and join the study tour in the Central Highlands. The author would like to thank ASS. Prof. Dr. Van Khanh Nguyen, ASS. Prof. Dr. Luong Trung Pham, ASS. Prof. DR. Lien Viet Tran who directly supervise and bring valuable suggestions to the author to improve the results of research.

\section{References}

1. Abetz B. (1996). Klimaänderung und Tourismus. Schlussbericht NFP 31. vdf Hochschulverlag AG an der ETH. Zürich.

2. Aizenshtat B.A., Lukina L.P. (1982). Bioclimatic microclimate of Tashkent. Leningrad: Hidrometeoizdat. [In Russian]. [Айзенштат Б.А., Лукина Л.П. Индекс биоклиматического микроклимата Ташкента. - Ленинград: Гидрометеоиздат, 1982.$]$

3. Amiranashvili A., Matzarakis A., Kartvelishvili L.(2008). Tourism Climate Index in Tbilisi. Transactions of the Georgian institute of hydrometeorology, vol.115, 27.

4. Amelung B., Viner D. (2006). Mediterranean Tourism: Exploring the Future with the Tourism Climatic Index. Journal of Sustainable Tourism, vol. 14, 4.

5. Dac T.P., Toan N.P. (1980). Climate Vietnam. Publishing scientific and technical Hanoi.

6. Scott D., McBoyle G., Schwartzentruber M. (2004). Climate change and the distribution of climatic resources for tourism in North America. Climate research, vol. 27, 105-117.

7. Hassan Rahmanpour, Hashem Jangi, Ali Beyk Khorasani Niya (2014). The study of comfort and tourism climate of Roshtkhar. Razavi Khorasan province - Iran. Reef Resources assessment and management technical paper, vol.40 (5), 60-70.

8. Jacqueline M., Hamilton, Maren A.L. (2004). The role of climate information in tourist destination choice decision making. Centre for Marine and Climate Research, Hamburg University, Hamburg, Germany. Working Paper FNU-56

9. Lien V.T. (1993). Climate with organized labor issues, recreation and tourism of Vietnamese territorial. General meteorological Hanoi.

10. Lien V.T. (2009). The Climate characteristics of Dien Bien Province. Thematic reports.

11. Matzarakis A., de Freitas C.R., Scott D. (2007). Developments in Tourism Climatology. 3rd International Workshop on Climate, Tourism and Recreation Alexandroupolis, Greece $19-22$ September.

12. Mieczkowski Z. (1985). The tourism climate index: A method for evaluating world climates for tourism. The Canadian Geographer, 29, 220-233

13. Ngu N.D., Hieu T.N. (1985). Climate Zoning Vietnam. General meteorological Hanoi.

14. Phong N.D. (1972). Weather with illness. Medical publishing House.

15. Van K.N. (1993). Rational use of resources for development bioclimatic for production and people's livelihood, tourism in Hoa Binh Lake. Journal of Earth Science, vol 3.

16. Van K.N., Hien T.N. (2000). Study bio climatic for health, Tourist Resort and livelihood of the people in Vietnam. Journal of Earth Science, vol 2.

17. World Tourism Organization (2014). UNWTO Tourism Highlights 20114 Edition.

18. Tavallaea S. (2008). Review of Tourism Industry. Tehran Teacher Training University. 